\title{
Removal of Harmful Anions in Aqueous Solution with Various Layered Double Hydroxides
}

\author{
Norihiro MURAYAMA $^{1,2 *}$, Daisuke SAKAMOTO ${ }^{1}$, Junji SHIBATA ${ }^{1}$ \\ and Marjorie VALIX ${ }^{2}$
}

${ }^{1}$ Department of Chemical, Energy and Environmental Engineering, Kansai University, Japan

${ }^{2}$ School of Chemical and Biomolecular Engineering, The University of Sydney, Australia

\begin{abstract}
Four types of layered double hydroxides (LDHs) were synthesized by a co-precipitation method. The ability of various LDHs to remove anionic species including $\mathrm{As}(\mathrm{III}), \mathrm{As}(\mathrm{V}), \mathrm{B}, \mathrm{Cr}(\mathrm{VI})$ and $\mathrm{Se}(\mathrm{IV})$ was investigated. Removal tests were performed primarily by a batch operation. The $\mathrm{Cr}(\mathrm{VI})$ removal was conducted by both batch and column studies. For the column removal tests, LDH pellets were prepared using a granulator and 5\% poly-vinyl alcohol solution as binder.

Among the LDHs tested, $\mathrm{Mg}-\mathrm{Al}-\mathrm{NO}_{3}{ }^{-} \mathrm{LDH}$ showed the optimal removal of anionic species, and it demonstrated excellent removal of $\mathrm{As}(\mathrm{V}), \mathrm{Se}(\mathrm{IV})$ and $\mathrm{Cr}(\mathrm{VI})$ particularly at the low anionic concentrations. The order of anionic removal by the LDHs is as follows; $\mathrm{Mg}-\mathrm{Al}-\mathrm{NO}_{3}{ }^{-} \mathrm{LDH}>\mathrm{Mg}-\mathrm{Al}-$ $\mathrm{Cl}^{-} \mathrm{LDH}>>\mathrm{Mg}-\mathrm{Al}-\mathrm{SO}_{4}{ }^{2-} \mathrm{LDH}>\mathrm{Mg}-\mathrm{Al}-\mathrm{CO}_{3}{ }^{2-} \mathrm{LDH}$. The selective uptake of anion had the following order; $\mathrm{As}(\mathrm{V})>\mathrm{Se}(\mathrm{IV})>\mathrm{Cr}(\mathrm{VI})>\mathrm{As}(\mathrm{III})>\mathrm{B}$. This study has demonstrated the uptake of harmful anions is influenced by the two specific factors, (1) the originally intercalated anions in the LDH, and (2) valency of anionic target species in aqueous solution. Column study also demonstrated that about 350 times $\mathrm{Cr}(\mathrm{VI})$ in solution per unit volume of LDH pellet can be removed, though this resulted in minor change in $\mathrm{pH}$ of the solution and greater $\mathrm{NO}_{3}^{-}$elution. This study has revealed the ability of LDH to remove harmful anionic species and its practical application in wastewater treatment.
\end{abstract}

Key words: Layered double hydroxide, Anion exchanger, Harmful anion, Water purification

\section{Introduction}

Layered double hydroxide (LDH), also referred to as anionic clay, consists of metal complex hydroxide structure; $\left[\mathrm{M}^{2+}{ }_{1-\mathrm{x}} \mathrm{M}^{3+}{ }_{\mathrm{x}}(\mathrm{OH})_{2}\right]^{\mathrm{x}} \cdot\left[\left(\mathrm{A}^{\mathrm{n}-}\right)_{\mathrm{x} / \mathrm{n}}\right.$. $\left.\mathrm{mH}_{2} \mathrm{O}\right]^{\mathrm{x}-}(\mathrm{x}=0.2-0.33)$. Here, $\mathrm{M}^{2+}$ and $\mathrm{M}^{3+}$ are divalent and trivalent metal ions, respectively, and $\mathrm{A}^{\mathrm{n}-}$ is the anionic species providing the inorganic anion exchanger functionality ${ }^{1,2}$. For example, the $\mathrm{Mg} / \mathrm{Al}$ type $\mathrm{LDHs}$ and $\mathrm{Ca} / \mathrm{Al}$ type $\mathrm{LDHs}$ belong to hydrotalcite and hydrocalumite mineral family, respectively. The positive charges at the $\mathrm{M}^{3+}$ sites in the metal hydroxide structure provide the anion exchange sites. This anion exchange property of LDH is attributed to capture anionic species by its intercalation within the interlayer structure ${ }^{1-4}$.

\footnotetext{
Accepted 25 October, 2012

*e-mail: murayama@kansai-u.ac.jp
}

Numerous papers have related the application of various LDHs including removal of harmful anions, carrier support for catalyst, a drug delivery system and so on ${ }^{5-12}$. Our works have reported the preparation of LDHs synthesized from reagent and industrial by-products including aluminum dross, dust and steelmaking slag with anionic species including As, B, Cr, Se, P, organic carboxylates and anionic surfactants and their application in wastewater treatment ${ }^{13-23}$. However, the systematic kinetics and equilibrium adsorption testing required for the design of a removal unit and the quantitative evaluation of the selectivity of LDHs prepared have not been adequate. In addition testing of the LDHs in continuous operation in a column absorber is quite limited.

In this study, various $\mathrm{Mg} / \mathrm{Al}$ type LDHs with $\mathrm{Cl}^{-}, \mathrm{NO}_{3}^{-}, \mathrm{CO}_{3}{ }^{2-}$ and $\mathrm{SO}_{4}{ }^{2-}$ as an exchangeable anion were synthesized by a co-precipitation 
MURAYAMA, SAKAMOTO, SHIBATA and VALIX

Table 1 Synthesis condition of various LDHs

\begin{tabular}{lllllc}
\hline & $\mathrm{LDH}$ & $\mathrm{Mg}$ source & Al source & Anion source & Synthesis $\mathrm{pH}$ \\
\hline (a) & $\mathrm{Mg}-\mathrm{Al}-\mathrm{NO}_{3}^{-}$ & $\mathrm{Mg}\left(\mathrm{NO}_{3}\right)_{2}$ & $\mathrm{Al}\left(\mathrm{NO}_{3}\right)_{3}$ & $\mathrm{NH}_{4} \mathrm{NO}_{3}$ & 11 \\
(b) & $\mathrm{Mg}-\mathrm{Al}-\mathrm{Cl}^{-}$ & $\mathrm{MgCl}_{2}$ & $\mathrm{AlCl}_{3}$ & $\mathrm{NH}_{4} \mathrm{Cl}$ & 11 \\
(c) & $\mathrm{Mg}-\mathrm{Al}-\mathrm{SO}_{4}{ }^{2-}$ & $\mathrm{MgSO}_{4}$ & $\mathrm{Al}_{2}\left(\mathrm{SO}_{4}\right)_{3}$ & $\left(\mathrm{NH}_{4}\right)_{2} \mathrm{SO}_{4}$ & 10 \\
(d) & $\mathrm{Mg}-\mathrm{Al}-\mathrm{CO}_{3}{ }^{2-}$ & $\mathrm{MgCl}_{2}$ & $\mathrm{AlCl}_{3}$ & $\mathrm{Na}_{2} \mathrm{CO}_{3}$ & 11 \\
\hline
\end{tabular}

method. The removal property of these LDHs for harmful anionic species including As(III), As(V), $\mathrm{B}, \mathrm{Cr}(\mathrm{VI})$ and $\mathrm{Se}(\mathrm{IV})$ was investigated. The removal of $\mathrm{Cr}(\mathrm{VI})$ was researched by batch and column operations. In the column tests, LDH pellets prepared using a granulator were used.

\section{Experimental}

\subsection{Synthesis of LDH by co-precipitation method}

Four types of $\mathrm{Mg} / \mathrm{Al}$ type $\mathrm{LDHs}$ with $\mathrm{NO}_{3}^{-}, \mathrm{Cl}^{-}$, $\mathrm{SO}_{4}{ }^{2-}$ and $\mathrm{CO}_{3}{ }^{2-}$ as an exchangeable anion were prepared by a co-precipitation method. In this study the naming convention used is exemplified by the following example, $\mathrm{Mg} / \mathrm{Al}$ type $\mathrm{LDH}$ containing $\mathrm{NO}_{3}^{-}$was referred to as "Mg-Al- $\mathrm{NO}_{3}^{-}$ LDH". The synthesis conditions of various LDHs are summarized in Table 1. The LDH samples used are also the same as those used in our previous study ${ }^{19}$. That is, the co-precipitation method is similar to that mentioned in our paper ${ }^{19}$, and this involved the addition of two metal salts to a solution containing the anionic guest species followed by appropriate $\mathrm{pH}$ adjustment. For example in the synthesis of $\mathrm{Mg}-\mathrm{Al}-\mathrm{NO}_{3}^{-} \mathrm{LDH}, 500 \mathrm{~cm}^{3}$ of $0.5 \mathrm{~mol} / \mathrm{dm}^{3} \quad \mathrm{Mg}\left(\mathrm{NO}_{3}\right)_{2}+0.2 \mathrm{~mol} / \mathrm{dm}^{3} \mathrm{Al}\left(\mathrm{NO}_{3}\right)_{3}$ were dropped into $250 \mathrm{~cm}^{3}$ of $0.64 \mathrm{~mol} / \mathrm{dm}^{3}$ $\mathrm{NH}_{4} \mathrm{NO}_{3}$ solution of whilst vigorous stirred with a magnetic stirrer. The solution $\mathrm{pH}$ was also adjusted at the same time to 11.0 with $30 \mathrm{w} / \mathrm{v} \% \mathrm{NaOH}$. In this test the ratio of $\mathrm{Mg}^{2+} / \mathrm{Al}^{3+}$ was set to be 2.5 . The precipitate was aged whilst stirred for $24 \mathrm{~h}$, then filtered, washed with distilled water and dried at $343 \mathrm{~K}$. Similar method was adopted in preparing $\mathrm{Mg}-\mathrm{Al}-\mathrm{Cl}^{-} \mathrm{LDH}, \mathrm{Mg}-\mathrm{Al}-\mathrm{SO}_{4}{ }^{2-} \mathrm{LDH}$ and $\mathrm{Mg}$ $\mathrm{Al}-\mathrm{CO}_{3}{ }^{2-} \mathrm{LDH}$ using $\mathrm{NH}_{4} \mathrm{Cl},\left(\mathrm{NH}_{4}\right)_{2} \mathrm{SO}_{4}$ and $\mathrm{Na}_{2} \mathrm{CO}_{3}$ as the guest anion species, respectively (see Table 1). Syntheses of each LDH were confirmed by an X-ray diffraction (Rigaku Co. Ltd., RINT-TTRIII). The resulting surface morphology was examined by a scanning electron microscopy (KEYENCE Co. Ltd., VE-9800).

\subsection{Anion removal with various $\mathrm{LDHs}$}

Removal tests using the $\mathrm{Mg}-\mathrm{Al}-\mathrm{NO}_{3}{ }^{-} \mathrm{LDH}$, $\mathrm{Mg}-\mathrm{Al}-\mathrm{Cl}^{-} \mathrm{LDH}, \mathrm{Mg}-\mathrm{Al}-\mathrm{SO}_{4}{ }^{2-} \mathrm{LDH}$ and $\mathrm{Mg}-\mathrm{Al}-$ $\mathrm{CO}_{3}{ }^{2-} \mathrm{LDH}$ were carried out using primarily batch operation to remove $\mathrm{As}(\mathrm{III}), \mathrm{As}(\mathrm{V}), \mathrm{B}, \mathrm{Cr}(\mathrm{VI})$ and $\mathrm{Se}(\mathrm{IV})$ as target materials. Removal of $\mathrm{Cr}(\mathrm{VI})$ were also conducted in column tests. The solutions containing the above toxic materials were prepared by dissolving $\mathrm{As}_{2} \mathrm{O}_{3}$ with dilute $\mathrm{NaOH}$ solution or by dissolving $\mathrm{H}_{3} \mathrm{AsO}_{4}, \mathrm{H}_{3} \mathrm{BO}_{3}, \mathrm{~K}_{2} \mathrm{CrO}_{4}$ and $\mathrm{H}_{2} \mathrm{SeO}_{3}$ with distilled water. The initial $\mathrm{pHs}$ of $\mathrm{As}(\mathrm{III}), \mathrm{As}(\mathrm{V}), \mathrm{B}, \mathrm{Cr}(\mathrm{VI})$ and $\mathrm{Se}(\mathrm{IV})$ solutions were about 11.0, 2.5, 6.0, 4.3 and 2.8, respectively.

Batch removal tests were carried out by contacting $0.3 \mathrm{~g}$ of LDHs with $30 \mathrm{~cm}^{3}$ of single component target material solution at various concentrations. The solution was agitated continuously with a vertical shaker (TAITEC Co. Ltd., SR-2DW). After $1 \mathrm{~h}$ the solution was filtered immediately and the concentration of the remaining target material was analyzed by inductively-coupled plasma spectrometers (Shimadzu Co. Ltd., ICPS-7000 Ver. 2 and ICPS-7510) using a standard procedure.

\subsection{Preparation method of pelletized LDH (LDH pellet)}

The dried $\mathrm{Mg}-\mathrm{Al}-\mathrm{NO}_{3}^{-} \mathrm{LDH}$ powder was pelletized using a pan type granulator (Toyo Seisakusyo Co. Ltd., DPZ-01) with $5 \mathrm{wt} \%$ polyvinyl alcohol (Kuraray Co. Ltd., Kuraray POVAL 217, abbreviated as PVA) solution as binder. The process involved placing the dried LDH powder into a rotating pan granulator and spraying the powder with the $5 \mathrm{wt} \%$ PVA solution to achieve a weight ratio of LDH: PVA solution of $100 \mathrm{~g}: 30 \mathrm{~g}$. The pelletized product was dried at $343 \mathrm{~K}$ for $24 \mathrm{~h}$. The dried pellets were sieved using $1.40 \mathrm{~mm}$ and $0.85 \mathrm{~mm}$ sieves, and then the product fraction of $0.85-1.40 \mathrm{~mm}$ were recovered as LDH sample (abbreviated as LDH pellet) to use for the removal tests. The apparent density of the LDH pellet measured by a specific gravity meter (Mettler Toledo Co. Ltd., SGM-6) was $1.85 \mathrm{~g} / \mathrm{cm}^{3}$. Characteristics of the LDH pellet are shown in Table 2.

\subsection{Cr(VI) removal with LDH pellet by batch and column operations}

Removal of $\mathrm{Cr}(\mathrm{VI})$ with the LDH pellet were carried out by both batch and column tests. The procedures for batch removal test are similar to that described in section 2.2. Column test was 
conducted using glass column, $565 \mathrm{~mm}$ height and $10 \mathrm{~mm}$ internal diameter. Ten grams of the pellets were packed in the column to achieve a height of $150 \mathrm{~mm}$ and volume of $11.8 \mathrm{~cm}^{3}$. The $100 \mathrm{mg} / \mathrm{dm}^{3}$ $\mathrm{Cr}(\mathrm{VI})$ solution was continuously metered into the column in a downward stream at the rate of SV4 $\left(0.79 \mathrm{~cm}^{3} / \mathrm{min}\right)$. The effluent from the bottom part of column was collected by a fraction collector (Toyo Seisakusyo Co. Ltd., CHF122SC). The concentrations of $\mathrm{Cr}(\mathrm{VI})$ and $\mathrm{NO}^{3-}$ remaining in the effluent were determined by the inductivelycoupled plasma spectrometers and by an ion chromatography (Nihon Dionex Co. Ltd., DX-500), respectively.

\section{Results and Discussion}

\subsection{Anion removal with various LDHs}

Figure 1 shows the XRD patterns of various LDHs synthesized by a co-precipitation method. The Mg-Al type LDH peak pattern was identified as the main crystalline material for all reaction products. The diffraction angle of the first peaks at around $2 \theta=11^{\circ}$ in Fig. 1(a)-(d) varied and this is attributed to the different exchangeable guest an-

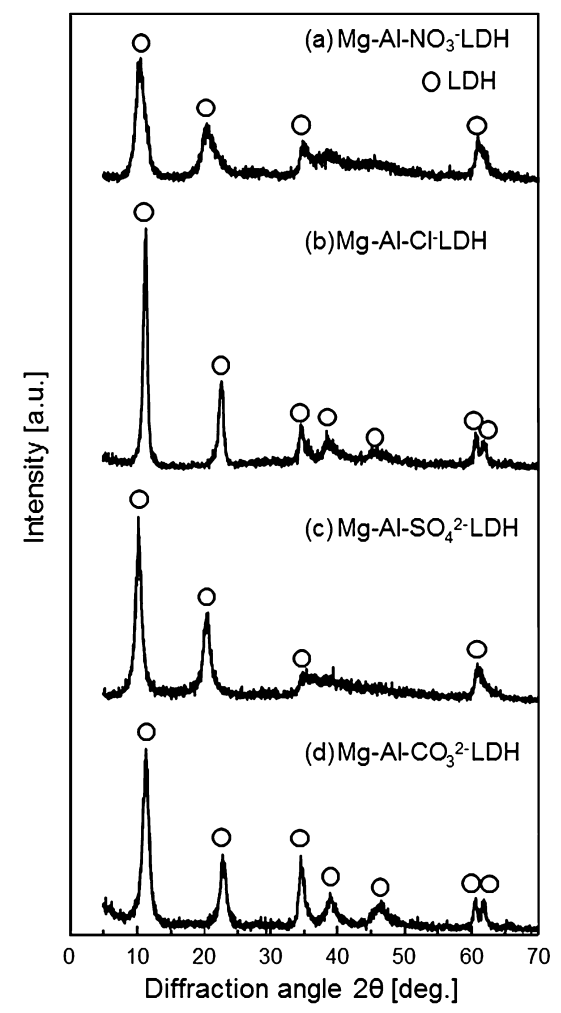

Fig. 1 XRD patterns of various LDH products ions in the LDH. These peaks are derived from the (006) plane of LDH structure, that is, the interlayer distance of reaction product. These are also found to shift corresponding to the size of exchangeable anion ${ }^{13,19}$. Though it is not shown in these figures, the anion exchange capacity of $\mathrm{Mg}$ $\mathrm{Al}-\mathrm{NO}_{3}^{-} \mathrm{LDH}$ may be estimated to be about $3.6 \mathrm{meq} / \mathrm{g}$ from the amount of $\mathrm{Al}$ in the $\mathrm{LDH}$ which is considered to be almost equal to the amount of anion exchange site. The exchange capacities of the other LDHs, Mg-Al- $\mathrm{Cl}^{-} \mathrm{LDH}$, $\mathrm{Mg}-\mathrm{Al}-\mathrm{SO}_{4}{ }^{2-} \mathrm{LDH}$ and $\mathrm{Mg}-\mathrm{Al}-\mathrm{CO}_{3}{ }^{2-} \mathrm{LDH}$ are considered to be about $3.5 \mathrm{meq} / \mathrm{g}, 3.1 \mathrm{meq} / \mathrm{g}$ and $3.5 \mathrm{meq} / \mathrm{g}$, respectively ${ }^{19}$.

The removal of various target anions with $\mathrm{Mg}$ $\mathrm{Al}-\mathrm{NO}_{3}{ }^{-} \mathrm{LDH}$ is illustrated in Figure 2. For comparison, the experimental data of $\mathrm{As}$ (III) and $\mathrm{As}(\mathrm{V})$ are quoted from our previous paper ${ }^{19}$. The equilibrium $\mathrm{pHs}$ after removal operation exist in the $\mathrm{pH}$ range between 7.2 to 10.6 by the $\mathrm{pH}$ buffer action of $\mathrm{LDH}^{15,18}$. From this $\mathrm{pH}$ range, the dominant anionic species of $\mathrm{As}(\mathrm{III}), \mathrm{As}(\mathrm{V}), \mathrm{B}, \mathrm{Cr}(\mathrm{VI})$ and $\mathrm{Se}(\mathrm{IV})$ are thought to be the forms such as $\mathrm{AsO}_{2}{ }^{-}, \mathrm{H}_{2} \mathrm{AsO}_{4}^{-}, \mathrm{HAsO}_{4}{ }^{2-}, \mathrm{HSeO}_{3}{ }^{-}, \mathrm{B}(\mathrm{OH})_{4}{ }^{-}$, $\mathrm{CrO}_{4}{ }^{2-}$ and $\mathrm{SeO}_{3}{ }^{2-}$. As shown in Figure 2, the removal of $\mathrm{As}(\mathrm{III}), \mathrm{As}(\mathrm{V})$ and $\mathrm{Se}(\mathrm{VI})$ increased with an increase in equilibrium concentration. On the other hand, in case of $\mathrm{Cr}(\mathrm{VI})$ and $\mathrm{B}$, their removals increased drastically with increasing equilibrium concentration in the region below $30 \mathrm{mg} / \mathrm{dm}^{3}$, but no further increase in removal was observed at the concentration above $30 \mathrm{mg} / \mathrm{dm}^{3}$. The selectivity for anion exchange has the following order; $\mathrm{As}(\mathrm{V})>\mathrm{Se}(\mathrm{IV})>\mathrm{Cr}(\mathrm{VI})>\mathrm{As}(\mathrm{III})>\mathrm{B}$. It is considered that this order is attributed to the difference in the valency of anionic species, in other

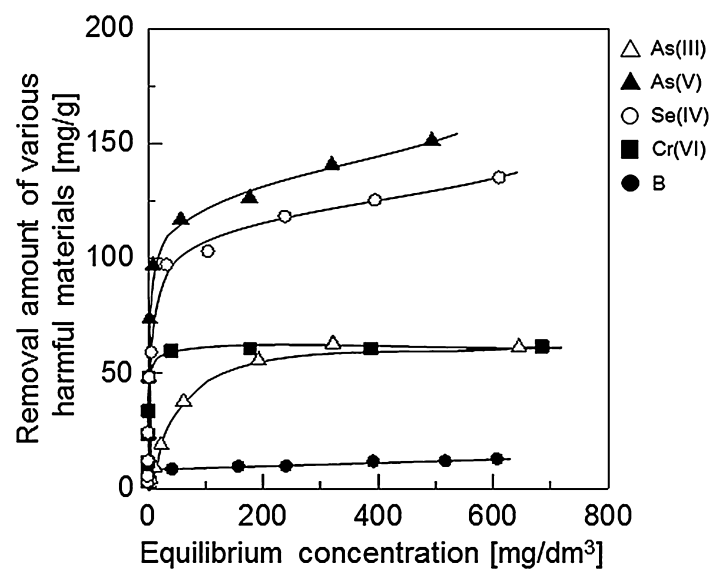

Fig. 2 Removal of various harmful anions with Mg-Al$\mathrm{NO}_{3}{ }^{-} \mathrm{LDH}$ 


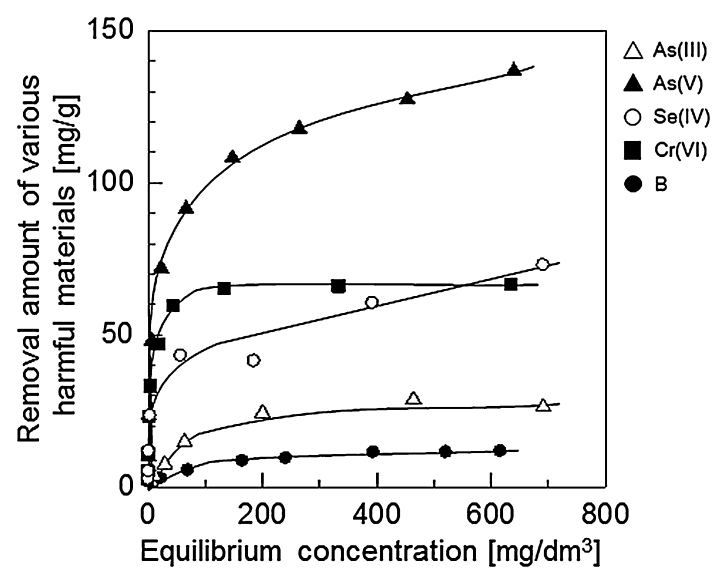

Fig. 3 Removal of various harmful anions with $\mathrm{Mg}-\mathrm{Al}-$ $\mathrm{Cl}^{-} \mathrm{LDH}$

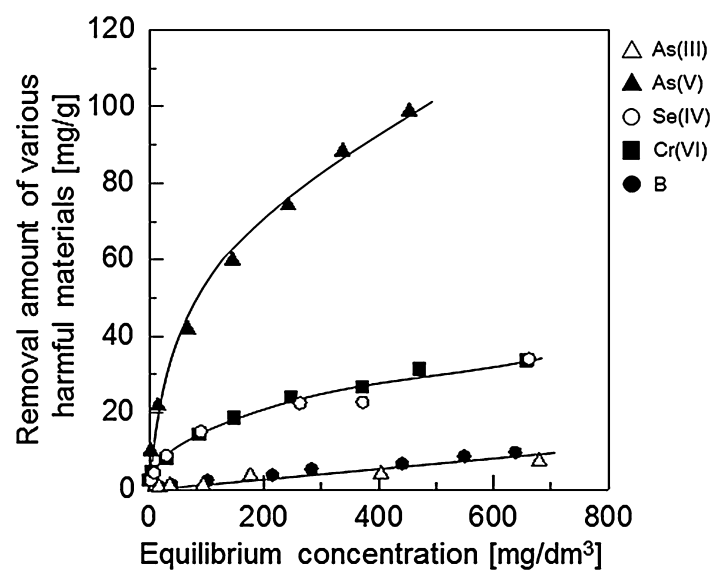

Fig. 4 Removal of various harmful anions with Mg-Al$\mathrm{SO}_{4}{ }^{2-} \mathrm{LDH}$

words, the anionic species with larger valency was favorably removed by LDH.

The removal properties of $\mathrm{Mg}-\mathrm{Al}-\mathrm{Cl}^{-} \mathrm{LDH}$, $\mathrm{Mg}-\mathrm{Al}-\mathrm{SO}_{4}{ }^{2-} \mathrm{LDH}$ and $\mathrm{Mg}-\mathrm{Al}-\mathrm{CO}_{3}{ }^{2-} \mathrm{LDH}$ are shown in Figures 3, 4 and 5, respectively. Here, the $\mathrm{As}(\mathrm{III})$ and $\mathrm{As}(\mathrm{V})$ are also cited data ${ }^{19}$. Among the target anions, $\mathrm{As}(\mathrm{V})$ was taken up selectively by all the LDHs. Whereas the removal of As(III) and $\mathrm{B}$ were found to be very low. The removal behavior of $\mathrm{Se}(\mathrm{IV})$ and $\mathrm{Cr}(\mathrm{VI})$ varied with the type of $\mathrm{LDH}$ with the following order; $\mathrm{Mg}-\mathrm{Al}-$ $\mathrm{NO}_{3}^{-} \quad \mathrm{LDH}>\mathrm{Mg}-\mathrm{Al}-\mathrm{Cl}{ }^{-} \quad \mathrm{LDH}>>\mathrm{Mg}-\mathrm{Al}-\mathrm{SO}_{4}{ }^{2-}$ $\mathrm{LDH}>\mathrm{Mg}-\mathrm{Al}-\mathrm{CO}_{3}{ }^{2-} \mathrm{LDH}$. The results show the divalent anions like $\mathrm{SO}_{4}{ }^{2-}$ or $\mathrm{CO}_{3}{ }^{2-}$ are stable in the LDH structure, and these do not participate well in the anion exchange reaction, unlike the monovalent anions like $\mathrm{NO}_{3}^{-}$or $\mathrm{Cl}^{-1,2,13}$. This is attributed to the stronger Coulomb's attractive force

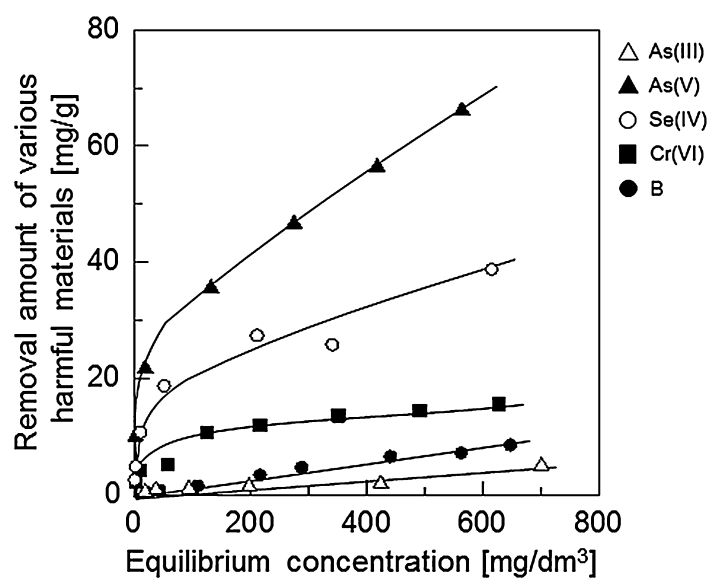

Fig. 5 Removal of various harmful anions with Mg-Al$\mathrm{CO}_{3}{ }^{2-} \mathrm{LDH}$

between divalent anions and positively charged exchange site in the $\mathrm{LDH}$, and also the weaker force in the case of monovalent anions. It appears the difference in the removal of target anionic species is influenced by the type of LDH and the valency of anionic species in aqueous solution. The results in Figures 2, 3, 4 and 5 demonstrated the $\mathrm{Mg}-\mathrm{Al}-\mathrm{NO}_{3}^{-} \mathrm{LDH}$ the best removal for the anionic species among four LDHs prepared in this study.

In general, the selectivity of an ion exchanger may be enhanced with the dilution of solution. The removal property of LDH for dilute solution within the ppm order is important from the viewpoint of the practical waste water treatment for the harmful anionic species. The removal behavior of $\mathrm{Mg}-\mathrm{Al}-\mathrm{NO}_{3}{ }^{-} \mathrm{LDH}$ which showed the best performance was investigated in detail, using dilute solutions below $100 \mathrm{mg} / \mathrm{dm}^{3}$. Figure 6 shows the ion exchange isotherms of harmful materials with the $\mathrm{Mg}-\mathrm{Al}-\mathrm{NO}_{3}{ }^{-} \mathrm{LDH}$ in low concentration region. The shape of isotherms for As(V), Se(IV) and $\mathrm{Cr}(\mathrm{VI})$ near $\mathrm{Y}$ axis showed a very sharp incline demonstrating the excellent performance of $\mathrm{Mg}$ $\mathrm{Al}-\mathrm{NO}_{3}{ }^{-} \mathrm{LDH}$ in the removal of anionic species from dilute solutions. The $\mathrm{Cr}(\mathrm{VI})$ removed was about $60 \mathrm{mg} / \mathrm{g}$, which corresponds to about $2.3 \mathrm{meq} / \mathrm{g}$ as a standard of $\mathrm{CrO}_{4}{ }^{2-}$. Therefore, $64 \%$ to the exchange capacity $(3.6 \mathrm{meq} / \mathrm{g})$ is estimated to be occupied with $\mathrm{CrO}_{4}{ }^{2-}$. Whereas the removal of As(III) and B is thought to be difficult as shown in Figure 6. The order of anion exchange in dilute solutions is similar to that shown in Figure 2, that is, $\mathrm{As}(\mathrm{V})>\mathrm{Se}(\mathrm{IV})>\mathrm{Cr}(\mathrm{VI})>\mathrm{As}(\mathrm{III})>\mathrm{B}$. 


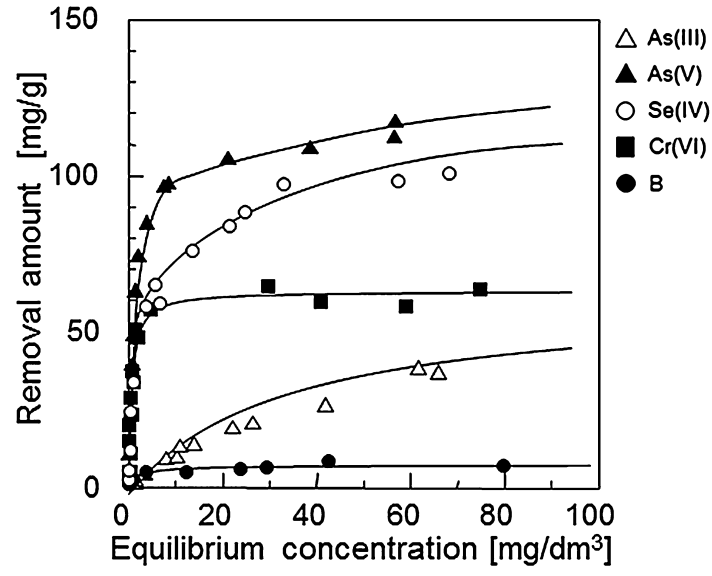

Fig. 6 Ion exchange isotherms of dilution solutions of harmful anions on $\mathrm{Mg}-\mathrm{Al}-\mathrm{NO}_{3}{ }^{-} \mathrm{LDH}$

Table 2 Preparation parameters and characterization of LDH pellets

\begin{tabular}{ll}
\hline Binder & $5 \mathrm{wt} \%$ PVA solution \\
Mixing ratio & $\begin{array}{l}100 \mathrm{~g} \text { of LDH: } 30 \mathrm{~g} \text { of PVA } \\
\text { solution }\end{array}$ \\
Particle size distribution & $0.85-1.40[\mathrm{~mm}]$ \\
Apparent pellet density & $1.85\left[\mathrm{~g} / \mathrm{cm}^{3}\right]$ \\
\hline
\end{tabular}

* Molecular weight of PVA: 221,000

\subsection{Cr(VI) removal with LDH pellet by batch and column operations}

Dried powder of the $\mathrm{Mg}-\mathrm{Al}-\mathrm{NO}_{3}{ }^{-} \mathrm{LDH}$ was pelletized under the condition shown in Table 2 by using the pan type granulator. Photograph 1 illustrates the SEM of the original LDH powder and pelletized product (LDH pellet). These photographs show that the LDH powder are characterized by block-like structure with smooth surface. The particle size distribution of the LDH is relatively wide from submicron to 50 or more micrometers. The LDH pellets have an elliptical shape with smooth surface, and fine particles of the $\mathrm{LDH}$ powder are found to be well agglomerated.

The rate of $\mathrm{Cr}(\mathrm{VI})$ removal by the $\mathrm{Mg}-\mathrm{Al}-\mathrm{NO}_{3}{ }^{-}$ $\mathrm{LDH}$ pellets is shown in Figure 7. The removal of $\mathrm{Cr}(\mathrm{VI})$ increased with a contact time but remained constant after $45 \mathrm{~min}$. At equilibrium, the $\mathrm{Cr}(\mathrm{VI})$ removed was about $9.5 \mathrm{mg} / \mathrm{g}$-LDH pellet. A slight increase in solution $\mathrm{pH}$ was observed due to the $\mathrm{pH}$ buffer action of LDH during the column test. This implies that the partial dissolution of metal hydroxide from the LDH structure may have taken place with its contact with weakly acidic $\mathrm{Cr}(\mathrm{VI})$ solution, that is, due to the potential instability of the LDH.

Figure 8 compares the removal of $\mathrm{Cr}(\mathrm{VI})$ be-

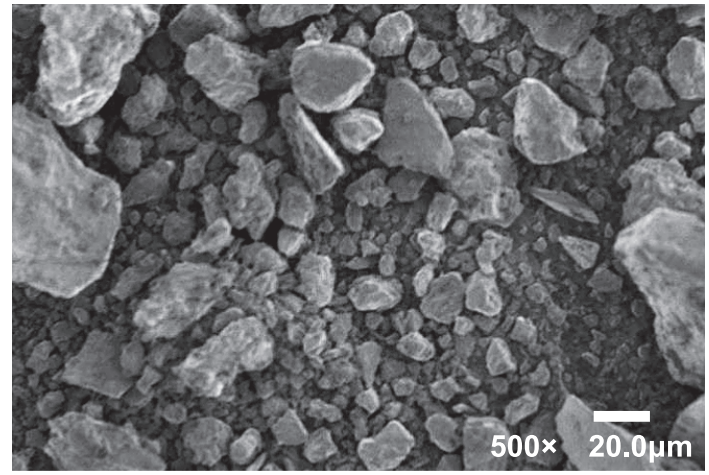

(a) Powder

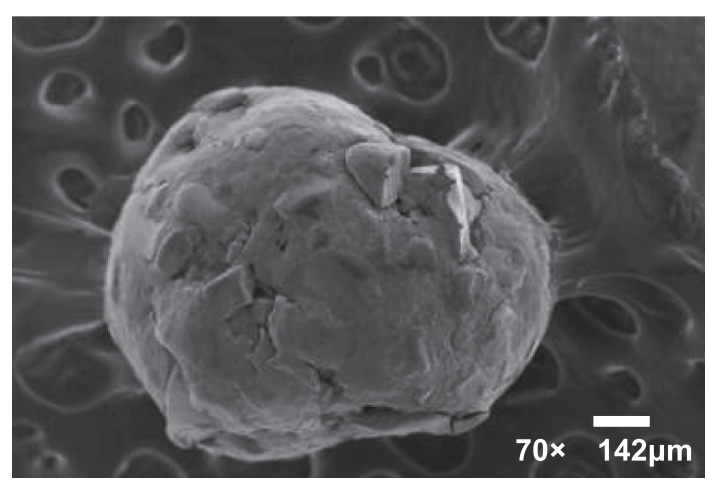

(b) Pellet

Photo. 1 SEM of (a) powdered and (b) pelletized Mg$\mathrm{Al}-\mathrm{NO}_{3}{ }^{-} \mathrm{LDH}$

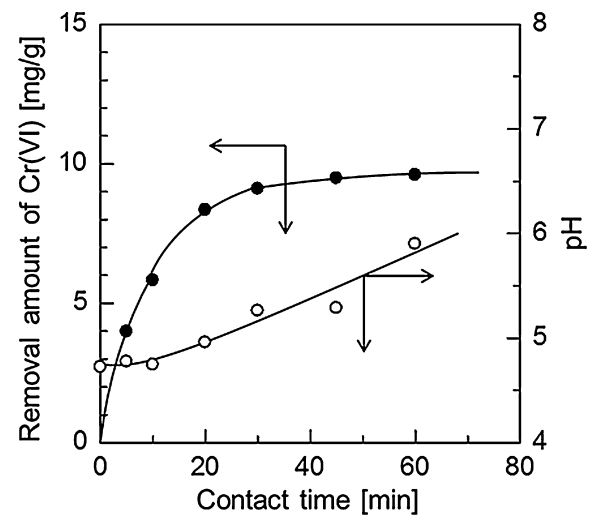

Fig. 7 Rate of $\mathrm{Cr}(\mathrm{VI})$ removal with $\mathrm{Mg}-\mathrm{Al}-\mathrm{NO}_{3}{ }^{-} \mathrm{LDH}$ pellet (Initial conc.: $100 \mathrm{mg} / \mathrm{dm}^{3}$, Solid-liquid ratio: $0.3 \mathrm{~g}: 30 \mathrm{~cm}^{3}$ )

tween powder and pelletized $\mathrm{Mg}-\mathrm{Al}-\mathrm{NO}_{3}{ }^{-} \mathrm{LDHs}$. The $\mathrm{Cr}(\mathrm{VI})$ removal by the LDH pellet increased remarkably at concentration below $10 \mathrm{mg} / \mathrm{dm}^{3}$ equilibrium concentration, and increased more gradually at the higher concentration. Although 


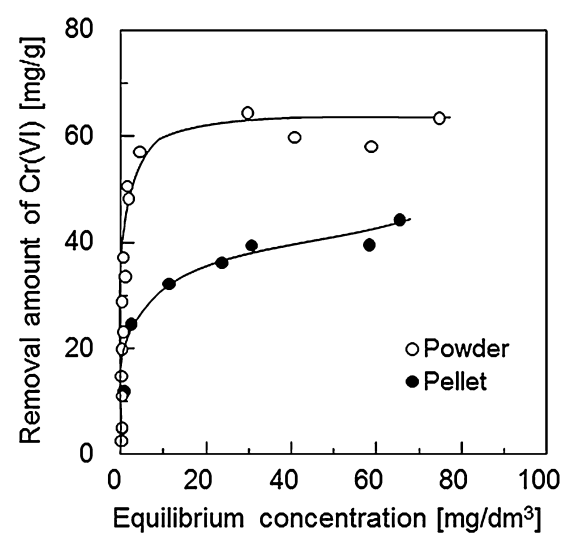

Fig. 8 Comparison of $\mathrm{Cr}(\mathrm{VI})$ removal between powder and pellet of $\mathrm{Mg}-\mathrm{Al}-\mathrm{NO}_{3}{ }^{-} \mathrm{LDH}$

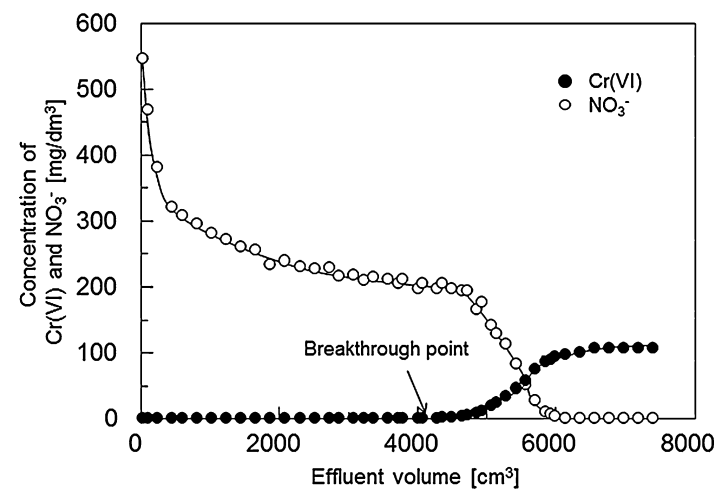

Fig. 9 Breakthrough curve for $\mathrm{Cr}(\mathrm{VI})$ removal on $\mathrm{Mg}$ $\mathrm{Al}-\mathrm{NO}_{3}{ }^{-} \mathrm{LDH}$ pellet (Initial conc.: $100 \mathrm{mg} / \mathrm{dm}^{3}$, Space velocity: 4 , Bed volume: $11.8 \mathrm{~cm}^{3}(=10 \mathrm{~g})$ )

the shapes of $\mathrm{Cr}(\mathrm{VI})$ removal curves exhibited by the LDH powder and LDH pellet are essentially similar, the amount removed by the pellets are about $20 \mathrm{mg} / \mathrm{g}$ lower than that of the LDH powder. It is considered that this phenomenon may be caused by the differences in surface area or efficiency of solid-liquid contact between LDH powder and LDH pellet. The advantage, however of the pellets is the ease of the solid-liquid separation and its applicability in continuous operation.

Figure 9 illustrates the breakthrough curve of $\mathrm{Cr}(\mathrm{VI})$ with the $\mathrm{Mg}-\mathrm{Al}-\mathrm{NO}_{3}^{-} \mathrm{LDH}$ pellet. No $\mathrm{Cr}(\mathrm{VI})$ elution is found until about $4,000 \mathrm{~cm}^{3}$ of effluent volume by the strong affinity of the LDH to $\mathrm{Cr}(\mathrm{VI})$. The breakthrough point was set to be the $0.5 \mathrm{mg} / \mathrm{dm}^{3}$ of $\mathrm{Cr}(\mathrm{VI})$ concentration which occurred with the $4,080 \mathrm{~cm}^{3}$ of effluent volume. This means that it is possible to treat about 350 times the $\mathrm{Cr}(\mathrm{VI})$ solution to the $\mathrm{LDH}$ pellet volume $\left(11.8 \mathrm{~cm}^{3}\right)$. At the $6140 \mathrm{~cm}^{3}$ of effluent volume, the $\mathrm{Cr}(\mathrm{VI})$ concentration approached about $100 \mathrm{mg} / \mathrm{dm}^{3}$ of initial concentration. In the region up to the breakthrough point, the total amount of $\mathrm{Cr}(\mathrm{VI})$ removed was estimated to be $0.93 \mathrm{meq} / \mathrm{g}$ LDH pellet.

On the other hand, $\mathrm{NO}_{3}{ }^{-}$is released from the $\mathrm{LDH}$, as a result of anion exchange reaction between anionic species of $\mathrm{Cr}(\mathrm{VI})$ in solution. The $\mathrm{NO}_{3}{ }^{-}$concentration gradually decreased with metering of effluent volume into the column becoming zero, when the effective anion exchange site in the LDH pellet was saturated under this condition and the outlet $\mathrm{Cr}(\mathrm{VI})$ concentration reached its initial concentration $\left(100 \mathrm{mg} / \mathrm{dm}^{3}\right)$ again. The total amount of $\mathrm{NO}_{3}{ }^{-}$released until the breakthrough point was calculated to be about $2.0 \mathrm{meq} / \mathrm{g}-\mathrm{LDH}$ pellet. The reason for the greater elution quantity of $\mathrm{NO}_{3}{ }^{-}$relative to $\mathrm{Cr}(\mathrm{VI})$ is not clarified yet, but it is considered that this is mainly caused by the elution of $\mathrm{NO}_{3}{ }^{-}$from anion exchange sites with the partial disintegration of LDH structure, that is to say, with partial dissolution of hydroxide parts in the $\mathrm{LDH}$ referred to earlier.

\section{Conclusion}

The removal properties of various $\mathrm{LDHs}, \mathrm{Mg}$ $\mathrm{Al}-\mathrm{NO}_{3}{ }^{-} \mathrm{LDH}, \mathrm{Mg}-\mathrm{Al}-\mathrm{Cl}{ }^{-} \mathrm{LDH}, \mathrm{Mg}-\mathrm{Al}-\mathrm{SO}_{4}{ }^{2-}$ $\mathrm{LDH}$ and $\mathrm{Mg}-\mathrm{Al}-\mathrm{CO}_{3}{ }^{2-} \mathrm{LDH}$ synthesized by a coprecipitation for anionic species including As(III), $\mathrm{As}(\mathrm{V}), \mathrm{B}, \mathrm{Cr}(\mathrm{VI})$ and Se(IV) were examined in this study. Removal tests were conducted by batch and column methods.

The $\mathrm{Mg}-\mathrm{Al}-\mathrm{NO}_{3}^{-} \mathrm{LDH}$ showed the best anionic removal among the four LDHs prepared in this study. The order of removal performance is as follows; $\mathrm{Mg}-\mathrm{Al}-\mathrm{NO}_{3}{ }^{-} \mathrm{LDH}>\mathrm{Mg}-\mathrm{Al}-\mathrm{Cl}^{-} \mathrm{LDH}>>$ $\mathrm{Mg}-\mathrm{Al}-\mathrm{SO}_{4}{ }^{2-} \mathrm{LDH}>\mathrm{Mg}-\mathrm{Al}-\mathrm{CO}_{3}{ }^{2-} \mathrm{LDH}$. This order suggests the stability of the divalent anions like $\mathrm{SO}_{4}{ }^{2-}$ or $\mathrm{CO}_{3}{ }^{2-}$ on the $\mathrm{LDH}$ structure and thus their poor exchange properties. The $\mathrm{Mg}-\mathrm{Al}-\mathrm{NO}_{3}{ }^{-}$ LDH demonstrated an excellent ability to remove dilute concentrations of $\mathrm{As}(\mathrm{V}), \mathrm{Se}(\mathrm{IV})$ and $\mathrm{Cr}(\mathrm{VI})$ with the following order; $\mathrm{As}(\mathrm{V})>\mathrm{Se}(\mathrm{IV})>\mathrm{Cr}(\mathrm{VI})$ $>\mathrm{As}(\mathrm{III})>\mathrm{B}$. The use of LDH pellets were shown to effectively treat about 350 times of the $\mathrm{Cr}(\mathrm{VI})$ solution to the $\mathrm{LDH}$ pellet volume in a column test. Although the pellets showed a lower $\mathrm{Cr}(\mathrm{VI})$ uptake amount of about $20 \mathrm{mg} / \mathrm{g}$ compared with the powdered LDH, the pellets application in column operations is a key advantage for the practical application of this adsorbent. The LDH also demonstrated some minor instability when contacted with the weak acidic effluent solutions. These are exhibited by the greater elution of $\mathrm{NO}_{3}{ }^{-}$ions rela- 
tive to $\mathrm{Cr}(\mathrm{VI})$ and change in $\mathrm{pH}$ resulting from the partial dissolution of the hydroxide component of the LDH. This study has revealed the ability of $\mathrm{LDH}$ in the practical removal of harmful anionic species from wastewater.

\section{Acknowledgements}

This research was partially supported by Kansai University's Overseas Research Program for the year of 2011 and the MEXT, Supported Program for the Strategic Research Foundation at Private Universities, 2012-2016.

\section{References}

1. E. Narita: Nendo Kagaku, 46, pp. 207-218 (2007)

2. S. Miyata: Clays and Clay Minerals, 31, pp. 305311 (1983)

3. K. Okada, K. Mimura, S. Nogi: Nendo Kagaku, 34, pp. 40-47 (1994)

4. S. Velu, A. Ramani, V. Ramaswamy, B.M. Chanda, S. Sivasanker: Studies in Surface Science and Catalysis, 118, pp. 941-950 (1998)

5. Y. Ono and E. Suzuki: Shokubai, 34, pp. 509-514 (1992)

6. T. Yamagishi, Y. Oyanagi, E. Narita: Nihon Kagakukaishi, 4, pp. 335-341 (1993)

7. F. Malherbe, C. Forano, J. Besse: Journal of Materials Science Letters, 18, pp. 1217-1219 (1999)

8. H. Hirahara, S. Aizawa, H. Sato, S. Takahashi, Y. Umetsu, E. Narita: Nendo Kagaku, 45, pp. 6-13 (2005)

9. Y. Chuang, Y. Tzou, M. Wang, C. Liu, P. Chiang: Industrial \& Engineering Chemistry Research, 47, pp. 3813-3819 (2008)
10. S. Vreysen and A. Maes: Applied Clay Science, 38, pp. 237-249 (2008)

11. L. Gaini, M. Lakraimi, E. Sebbar, A. Meghea, M. Bakasse: Journal of Hazardous Materials, 161, pp. 627-632 (2009)

12. T. Kameda, H. Takeuchi, T. Yoshioka: Materials Research Bulletin, 44, pp. 840-845 (2009)

13. N. Murayama, H. Yamamoto, J. Shibata: Kankyo Shigen Kogaku, 51, pp. 92-98 (2004)

14. J. Shibata, N. Murayama, M. Tanabe, H. Yamamoto: Kagaku Kogaku Ronbunshu, 31, pp. 74-79 (2005)

15. N. Murayama, M. Tanabe, R. Shibata, H. Yamamoto, J. Shibata: Kagaku Kogaku Ronbunshu, 31, pp. 285-290 (2005)

16. N. Murayama, J. Shibata, K. Sakai, S. Nakajima, H. Yamamoto: Kankyo Shigen Kogaku, 53, pp. 611 (2006)

17. J. Shibata, N. Murayama, H. Yamamoto: Japanese Patent Disclosure, H06-151744 (2006)

18. J. Shibata, N. Murayama, S. Nakajima: Kagaku Kogaku Ronbunshu, 33, pp. 273-277 (2007)

19. J. Shibata, N. Murayama, D. Sakamoto, M. Okada: Kagaku Kogaku Ronbunshu, 35, pp. 6065 (2009)

20. N. Murayama, H. Ushiro, S. Hattori, T. Miyoshi, J. Shibata: Kagaku Kogaku Ronbunshu, 37, pp. 526-531 (2011)

21. N. Murayama, I. Maekawa, H. Ushiro, J. Shibata, E. Udagawa: Kagaku Kogaku Ronbunshu, 38, pp. 176-182 (2012)

22. N. Murayama, I. Maekawa, H. Ushiro, Y. Moyoshi, J. Shibata, M. Valix: International Journal of Mineral Processing, 110-111, pp. 46-52 (2012)

23. N. Murayama, R. Hara, T. Miyoshi, J. Shibata, E. Udagawa: Kagaku Kogaku Ronbunshu, 38, pp. 234-241 (2012) 